\title{
Biosorption Removal of Methylene Blue Dye from Aqueous Solutions using Phosphoric Acid-Treated Balanites Aegyptiaca Seed Husks Powder
}

\author{
Ibrahim A. Amar ${ }^{1 *}{ }^{*}$, Esra A. Zayid ${ }^{1}$, Seada A. Dhikeel ${ }^{1}$, Mohamed Y. Najem ${ }^{1}$ \\ 1 Department of Chemistry, Faculty of Science, Sebha University, Sebha, Libya; ibr.amar@sebhau.edu.ly (I.A.A.); \\ esrazayid@gmail.com (E.A.Z.); sadaadhikeel@gmail.com (S.A.D.); owhida111986@gmail.com (M.Y.N.); \\ * Correspondence: ibr.amar@sebhau.edu.ly (I.A.A.);
}

Scopus Author ID 36968572200

Received: 15.10.2021; Revised: 15.11.2021; Accepted: 18.11.2021; Published: 2.12.2021

\begin{abstract}
Water contamination caused by the presence of synthetic dye is one of the world's major environmental concerns. This work aims to explore the potential application of non-carbonized phosphoric acid-treated Balanites aegyptiaca "heglig" seed husks powder (BASHP) as a bio-sorbent for methylene blue (MB) removal from water bodies. BASHP was characterized using Fourier transform infrared spectroscopy (FTIR). The characteristics of BASHP, such as the iodine number, point of zero charges, solubility, and specific surface area $\left(S_{\mathrm{MB}}\right)$ were also estimated. The biosorption of MB onto the BASHP surface was studied in batch mode under various conditions (contact time, shaking speed, solution temperature, initial solution $\mathrm{pH}$, ionic strength, initial dye concentration, and biosorbent dosage). The adsorption kinetics and isotherm were better described by pseudo-second-order and Langmuir models, respectively. More than $97 \%$ of MB was removed, and the maximum biosorbed amount of MB $\left(q_{\max }\right)$ was $72.99 \mathrm{mg} / \mathrm{g}$. Thermodynamics findings revealed that the proposed biosorption is an endothermic and spontaneous process. These findings showed that BASHP is a potentially ecofriendly, easily available, and low-cost material for removing hazardous dyes (e.g., methylene blue) from an aquatic environment, as well as a promising method for reducing agricultural solid waste (e.g., seed husks).
\end{abstract}

Keywords: Balanites aegyptiaca; seed husks; textile dyes; biosorption; adsorptive dye removal; lowcost adsorbents; agricultural solid wastes

(C) 2021 by the authors. This article is an open-access article distributed under the terms and conditions of the Creative Commons Attribution (CC BY) license (https://creativecommons.org/licenses/by/4.0/).

\section{Introduction}

Wastewater from the textile industry, which contains large amounts of residual dyes, is regarded as the primary source of water pollution [1,2]. Due to their toxic, mutagenic, and carcinogenic nature, the presence of dyes in water bodies, even at low concentrations, is extremely hazardous to human health and aquatic life [3,4]. Methylene blue (MB), a basic textile dye (Figure 1), is commonly used to color silk, wool, and cotton. Exposure to MB can cause difficulty breathing, mental confusion, eye burns, methemoglobinemia, sweating, nausea, vomiting, and profuse sweating [3]. Thus, removing synthetic dyes such as MB before they are released into bodies of water is critical for the environment.

Currently, various technologies such as flotation [5], nanofiltration [6], coagulation/flocculation [7], electrochemical oxidation [8], photocatalytic degradation [9] and adsorption $[10,11]$ are used to treat dye-contaminated water. Adsorption is the preferred 
method among these because of its simplicity, low cost, adsorbent versatility, and high efficiency [12]. Because of its high efficiency, activated carbon is the most commonly used adsorbent in many industries. However, its high production costs, as well as disposal, regeneration, and loss issues, limit its use [12,13]. This emphasizes the need for alternatives that are affordable, cost-effective, and environmentally friendly.

Biosorption has been extensively studied in recent years for removing water pollutants (e.g., heavy metals and dyes) using agricultural solid wastes (e.g., fruits peels, seeds, leaves barks) as adsorbent materials [4,14]. Biosorbents are advantageous because they are costeffective, environmentally friendly, renewable, and require less processing time [3,4]. Various materials, such as cauliflower leave [15], Terminalia catappa shell [11], Jojoba seeds [16], macadamia seed husks [12], and Haloxylon Recurvum plant stem [17], are being investigated as potential biosorbents for removing dyes from aquatic media.

Balanites aegyptiaca (L) Del., Desert date (Figure 2a), also known as "Heglig" in Arabic, is a tree native to Africa and South Asia. It is commonly used in traditional herbal medicine to treat wounds, intestinal worm infection, and jaundice, among other things [18]. Balanites aegyptiaca has recently been studied for its potential use in the removal of water pollutants. Activated carbon derived from the shells of Balanites aegyptiaca has been used successfully for the adsorptive removal of safranin dye [19] and heavy metal ions $\left(\mathrm{Ni}^{2+}\right.$ and $\mathrm{Cu}^{2+}$ ) [20] from aqueous solutions. However, compared to biosorbents, activated carbon requires a longer and more expensive production process, resulting in a high cost of dye removal [11]. To the best of the authors' knowledge, there is no report in the literature on using non-carbonized phosphoric acid-treated Balanites aegyptiaca seed husks powder (BASHP) for the adsorptive removal of $\mathrm{MB}$ from an aqueous medium. Phosphoric acid was used to treat BASHP biosorbent due to its low toxicity compared to other activation agents (e.g., $\mathrm{ZnCl}_{2}$ ) and its ability to provide high surface area and porosity materials, which are important for high adsorption performance [21]. Therefore, the current study aims to investigate the potential application of BASHP as a low-cost and environmentally friendly adsorbent for the removal of methylene blue, MB, a basic textile dye (Figure 1).

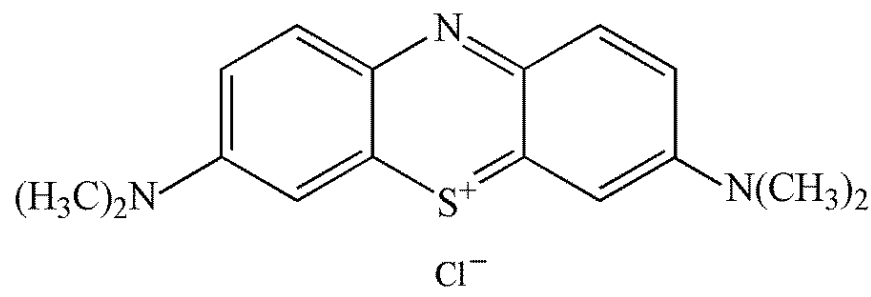

Figure 1. The molecular structure of methylene blue (MB).

\section{Materials and Methods}

\subsection{Materials.}

Seed husks of Balanites aegyptiaca "heglig" were collected from the local trees (grow in Sebha, Libya). Sodium thiosulfate and methylene blue dye, $\mathrm{MB},\left(\mathrm{C}_{16} \mathrm{H}_{18} \mathrm{ClN}_{3} \mathrm{~S} \cdot \mathrm{xH}_{2} \mathrm{O}, \mathrm{x}=\right.$ 2-3) were purchased from $\mathrm{ScP}$ (Surechem products). Phosphoric acid $\left(\mathrm{H}_{3} \mathrm{PO}_{4}\right)$ was purchased from ASIA chemicals. Sodium chloride $(\mathrm{NaCl})$, hydrochloric acid $(\mathrm{HCl})$, and iodine solution were purchased from BDH Chemicals. Sodium hydroxide $(\mathrm{NaOH})$ was obtained from Fluka. 


\subsection{Biosorbent preparation.}

The collected Balanites aegyptiaca "heglig" seed husks (Figure 2b) were washed several times with tap water, then with deionized water to remove dust, and finally dried overnight in an oven at $105^{\circ} \mathrm{C}$. A fine Balanites aegyptiaca seed husks powder (BASHP) with a particle size of $0.0125 \mathrm{~mm}$ was obtained after grinding dried seed husks using a pestle and mortar and sieving them. The BASHP $(50 \mathrm{~g})$ was then immersed in a 3:10 phosphoric acid solution for 12 hours before being filtered, washed, dried in an oven at $105{ }^{\circ} \mathrm{C}$, ground, and sieved to obtain acid-treated BASHP with a particle size of $0.0125 \mathrm{~mm}$ (Figure 2c). Finally, the prepared biosorbent material (acid-treated BASHP) was sealed in an airtight plastic container for the batch adsorption experiments.

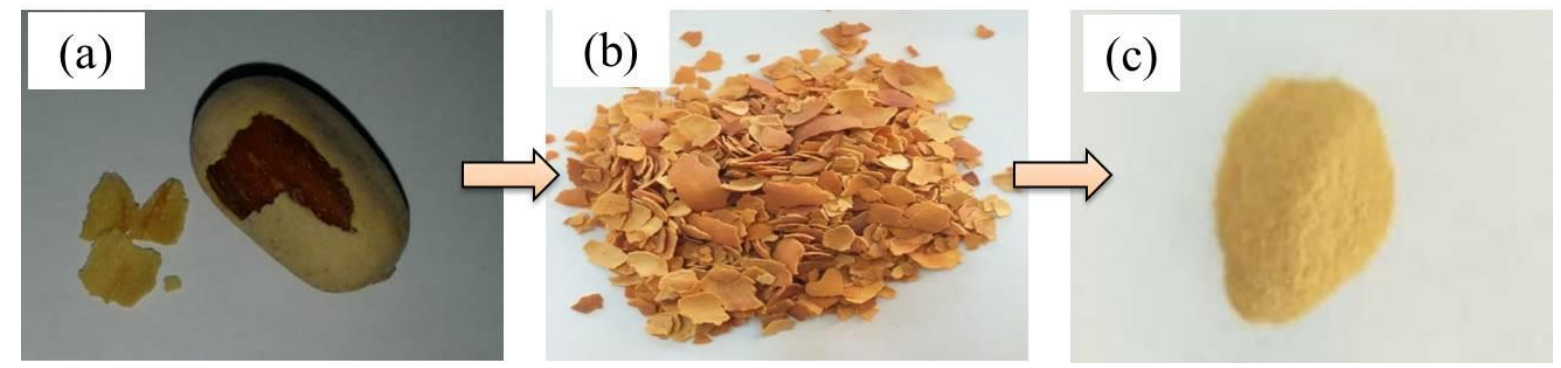

Figure 2. Photographic images. (a) Balanites aegyptiaca "heglig" date; (b) Balanites aegyptiaca seed husks; (c) acid-treated Balanites aegyptiaca seed husks powder (BASHP).

\subsection{Biosorbent characterization.}

Fourier transform infrared (FTIR) spectroscopy was used to investigate the biosorbent (acid-treated BASHP) functional groups using Nicolet 380 spectrometer. The FTIR spectrum of BASHP was recorded using the $\mathrm{KBr}$ disc method at room temperature in the wavenumber range $400-4000 \mathrm{~cm}^{-1}$. A salt addition method was used to estimate the $\mathrm{pH}$ at the point of zero charge ( $\mathrm{pH}$ PZC) of acid-treated BASHP, as described elsewhere [22]. The biosorbent's $\mathrm{pH}$ and conductivity were also determined according to ASTM D3838-80 [23]. The iodine number (mg of iodine/g of biosorbent) [24], moisture content (\%) and bulk density $\left(\mathrm{g} / \mathrm{cm}^{3}\right)$ of BASHP were determined [25]. The simple methylene blue method was used to estimate the specific surface area $\left(S_{\mathrm{MB}}\right)$ of acid-treated BASHP [13]. The solubilities of BASHP samples were determined as previously described [26].

\subsection{Adsorption studies.}

\subsubsection{Batch adsorption experiments.}

In this study, a batch mode was used to investigate the biosorption of MB dye onto an acid-treated BASHP biosorbent. The experiments were carried out in Erlenmeyer flasks (100 $\mathrm{mL}$ ) containing $20 \mathrm{~mL}$ of the desired concentration of $\mathrm{MB}$ dye and the required amount of the biosorbent. The flasks were shaken for pre-determined time and speed using Stuart orbital shaker, at room temperature, otherwise indicated. The factors affecting the biosorption process such as shaking speed (150 to $300 \mathrm{rpm}$ ), contact time (0-120 min), initial MB concentration $(100-300 \mathrm{mg} / \mathrm{L})$, adsorbent dosage $(0.02-0.12 \mathrm{~g} / 20 \mathrm{~mL})$, solution temperature $\left(25-45^{\circ} \mathrm{C}\right)$ and initial solution $\mathrm{pH}$ (4-13) were investigated. The MB dye solution's initial $\mathrm{pH}$ was adjusted to the desired value using a solution of either $\mathrm{NaOH}$ or $\mathrm{HCl}(0.1 \mathrm{~mol} / \mathrm{L})$. The experiments were 
conducted in triplicate. After each adsorption experiment, the biosorbent was separated by centrifugation at $2500 \mathrm{rpm}$ for 5 minutes. A single beam UV-Vis spectrophotometer (GENESYS $10 \mathrm{UV}$, Thermo Electron Corporation), at a maximum wavelength $\left(\lambda_{\max }\right)$ of 662 $\mathrm{nm}$, was used to estimate the initial and residual MB concentrations. The following equation was used to estimate the percentage removal of MB $(\% R)$ [27]:

$$
\% R=\frac{C_{\mathrm{o}}-C_{t}}{C_{\mathrm{o}}} \times 100
$$

where, $C_{\mathrm{o}}$ and $C_{t}$ are the initial concentration and the final concentrations at any time $t$ of MB dye solution $(\mathrm{mg} / \mathrm{L})$, respectively.

Equations (2) and (3) were used to calculate the adsorbed amounts of MB dye onto the biosorbent surface at any time $t\left(q_{t}, \mathrm{mg} / \mathrm{g}\right)$ and the equilibrium $\left(q_{e}, \mathrm{mg} / \mathrm{g}\right)$ as follows [12]:

$$
\begin{aligned}
& q_{t}=\frac{V\left(C_{\mathrm{o}}-C_{t}\right)}{m} \\
& q_{e}=\frac{V\left(C_{\mathrm{o}}-C_{e}\right)}{m}
\end{aligned}
$$

where $V(\mathrm{~L}), \quad C_{e}(\mathrm{mg} / \mathrm{L})$ and $m(\mathrm{~g})$ represent the volume of $\mathrm{MB}$ dye solution, MB dye concertation at the equilibrium, and biosorbent dosage, respectively.

\subsubsection{Adsorption kinetic models.}

The biosorption kinetics were investigated using two well-known models: pseudo-firstorder (PFO) and pseudo-second-order (PSO) [17,28]. The PFO kinetic model's linear form is as follows [17]:

$$
\ln \left(q_{e}-q_{t}\right)=\ln q_{e}-k_{1} t
$$

where, $k_{1}\left(\mathrm{~min}^{-1}\right)$ and $q_{e}(\mathrm{mg} / \mathrm{g})$ represent the PFO kinetic model rate constant and the calculated adsorbent capacity, respectively. The intercept and slope of the plot of $\ln \left(q_{e}-q_{t}\right)$ versus $t$, respectively, were used to estimate the values of $q_{e}$ and $k_{1}$.

The linearized form of the PSO kinetic model is as follows [29]:

$$
\frac{t}{q_{t}}=\frac{1}{k_{2} q_{\mathrm{e}}^{2}}+\frac{t}{q_{\mathrm{e}}}
$$

where, $k_{2}(\mathrm{~g} / \mathrm{mg} \mathrm{min})$ denotes the PSO kinetic model rate constant. The intercept and slope of the $t / q_{\mathrm{e}}$ versus $t$ plot were used to calculate the $k_{2}$ and $q_{e}$ values, respectively.

\subsubsection{Adsorption isotherms.}

In this study, the biosorption isotherms were described using two well-known models, Langmuir and Freundlich [30]. The linearized Langmuir isotherm form is written as [13]:

$$
\frac{C_{e}}{q_{e}}=\frac{1}{q_{\max } K_{L}}+\frac{C_{e}}{q_{\max }}
$$

where, $q_{\max }(\mathrm{mg} / \mathrm{g})$ and $K_{L}(\mathrm{~L} / \mathrm{mg})$ represent the maximum adsorbed amount of $\mathrm{MB}$ and, respectively, the Langmuir isotherm model constant. The intercept and slope of $C_{e}$ versus plot of $C_{e} / q_{e}$ plot were used to estimate the $K_{L}$ and $q_{\max }$ values. The separation factor $\left(R_{L}\right)$ expresses the essential feature of the Langmuir model, as shown below [22]:

$$
R_{L}=\frac{1}{1+K_{L} C_{\mathrm{o}}}
$$


The isotherm type is determined by the $R_{L}$ value, which can be linear $\left(R_{L}=1\right)$, favorable $\left(0<R_{L}<1\right)$, unfavorable, $\left(R_{L}>1\right)$, or irreversible $\left(R_{L}=0\right)$.

Freundlich isotherm is represented mathematically by the linearized form shown below [31]:

$$
\ln q_{e}=\ln K_{F}+\frac{1}{n} \ln C_{e}
$$

where, $K_{F}\left(\mathrm{mg} / \mathrm{g}(\mathrm{L} / \mathrm{mg})^{1 / \mathrm{n}}\right)$ represents the Freundlich constant. The Freundlich intensity parameter, $n$ (dimensionless), represents the magnitude of surface heterogeneity. If the value of $n$ is greater than unity ( $\mathrm{n}>1$ ), the adsorption conditions are favorable [31]. The slope and intercept of the $\ln q_{e}$ against $\ln C_{\text {e }}$ plot are used to estimate the $K_{F}$ and $n$ values, respectively.

\subsubsection{Adsorption thermodynamics.}

In this study, the adsorption thermodynamics was interpreted by Gibb's free energy change $\left(\Delta G^{\mathrm{o}}, \mathrm{kJ} / \mathrm{mol}\right)$ and enthalpy change $\left(\Delta H^{\mathrm{o}}, \mathrm{kJ} / \mathrm{mol}\right)$ entropy change $\left(\Delta S^{\mathrm{o}}, \mathrm{J} / \mathrm{mol} . \mathrm{K}\right)$. The following equations were used to calculate the values of thermodynamic parameters [13,32]:

$$
\begin{gathered}
\Delta G^{o}=\Delta H^{o}-T \Delta S^{o} \\
\ln K_{c}=\frac{-\Delta H^{o}}{R} \frac{1}{T}+\frac{\Delta S^{o}}{R} \\
K_{c}=\frac{C_{s}}{C_{e}}
\end{gathered}
$$

where, $C_{s}$ is the MB concentration $(\mathrm{mg} / \mathrm{L})$ onto the biosorbent surface, $T$ is the absolute temperature $(\mathrm{K}), R$ is the universal gas constant $(8.314 \mathrm{~J} / \mathrm{mol} / \mathrm{K})$, and $K_{c}$ is the distribution coefficient (dimensionless constant). The $K_{c}$ value was calculated using equation (11). The slope was used to calculate the value of $\Delta H^{O}$, while the intercept of $\Delta H^{o}$ against (1/T) plot was used to estimate the value of $\Delta S^{o}$.

\subsubsection{Desorption.}

Desorption experiments were carried out as follows: $20 \mathrm{~mL}$ of $\mathrm{MB}$ dye solution (concentration $100 \mathrm{mg} / \mathrm{L}$ ) was stirred with $0.12 \mathrm{~g}$ of biosorbent for $30 \mathrm{~min}$ at $45{ }^{\circ} \mathrm{C}$ in a magnetic stirrer $(150 \mathrm{rpm})$. The MB-loaded biosorbent (acid-treated BASHP) was then separated from the mixture by filtering. A mixed solution of ethanol and acetic acid (96: 4 V/V\%) was used as an eluent. The MB-loaded acid-treated BASHP was placed in a $20 \mathrm{~mL}$ solution of the eluent (ethanol and acetic acid) and stirred for $30 \mathrm{~min}$ at a speed of $150 \mathrm{rpm}$. The sample (acid-treated BASHP) was dried and reused after regeneration, and the removal percentage $(\% R)$ of $\mathrm{MB}$ was calculated after each cycle.

\section{Results and Discussion}

\subsection{Biosorbent characteristics.}

The surface functional groups of untreated and acid-treated biosorbent (BASHP) were identified using FTIR, and the results are presented in Figure 3. As shown, the FTIR spectra of both samples were nearly identical, indicating the presence of the same functional groups. For instance, the band at $3452 \mathrm{~cm}^{-1}$ in an untreated BASHP sample (red curve) is attributed to the stretching vibration of $\mathrm{O}-\mathrm{H}$ groups (carboxylic acids, phenols, and alcohols) [32]. The absorption band located at $2925 \mathrm{~cm}^{-1}$ is due to stretching vibrations of $\mathrm{C}-\mathrm{H}$ [32,33]. The band 
located at $2355 \mathrm{~cm}^{-1}$ is due to the presence of $\mathrm{CO}_{2}$ group [34]. The bands located at 1444 and $1645 \mathrm{~cm}^{-1}$ are attributed $\mathrm{C}-\mathrm{C}$ bonding and $\mathrm{N}-\mathrm{H}$ groups, respectively [33]. The absorption band located at $1022 \mathrm{~cm}^{-1}$ is assigned to stretching vibrations $\mathrm{C}-\mathrm{O}$ in carboxylic acids, alcohols, esters, and ethers [15,35]. The bands at 478,561 , and $874 \mathrm{~cm}^{-1}$ correspond to $\mathrm{C}-\mathrm{H}$ bonding, while the band at $673 \mathrm{~cm}^{-1}$ corresponds to alkali halides (C-Cl) [36].

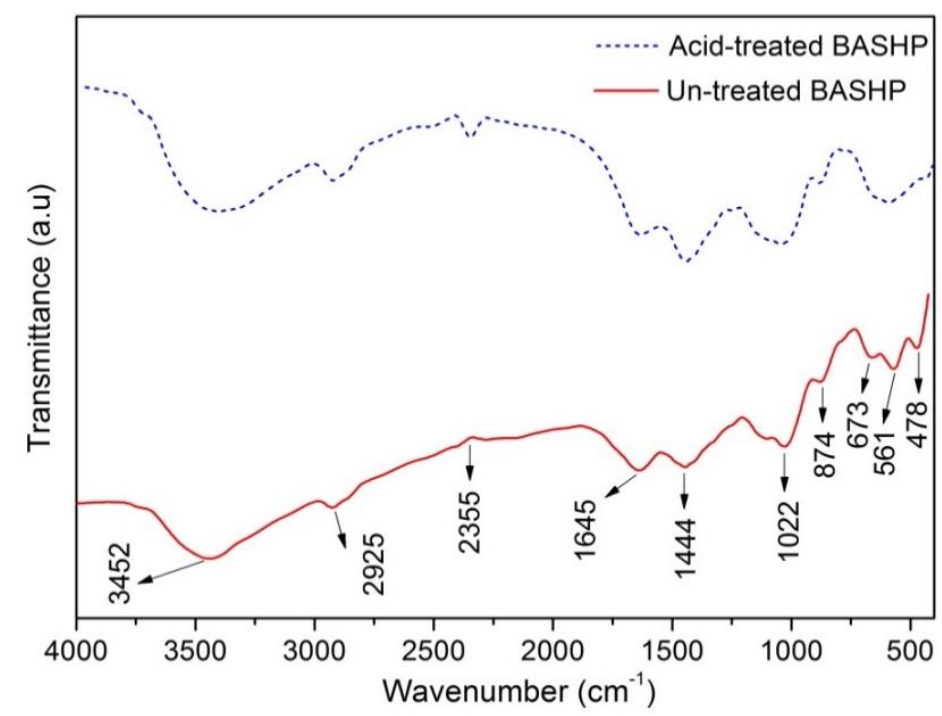

Figure 3. FTIR spectra of BASHP before and after acid treatment.

In this study, the iodine number of treated and acid-treated BASPH samples was also determined. The iodine number of the untreated sample was $174.42 \mathrm{mg} / \mathrm{g}$, which is lower than that of acid-treated BASPH $(803.27 \mathrm{mg} / \mathrm{g})$, indicating the high porosity and surface area of acid-treated BASPH. Also, the simple and inexpensive methylene blue method was used to determine the specific surface area $\left(S_{\mathrm{MB}}\right)$ of acid-treated BASHP [13,29], which is estimated to be $271.04 \mathrm{~m}^{2} / \mathrm{g}$. This value is lower than that of Casuarina equisetifolia needle $\left(351 \mathrm{~m}^{2} / \mathrm{g}\right)$ [29], which was determined using the same method. The solubility of the untreated sample was $7.2 \%$, while that of the acid-treated BASHP was $0.4 \%$. Besides, both BASHP samples had moisture content (\%) values of $0.98 \%$ (untreated) and $0.96 \%$ (acid-treated). The bulk densities of untreated and acid-treated BASHP samples, respectively, were 0.3984 and $0.3404 \mathrm{~g} / \mathrm{cm}^{3}$. These values are slightly higher than the recommended lower limit for granular activated carbon $\left(0.25 \mathrm{~g} / \mathrm{cm}^{3}\right)$ [37].

The $\mathrm{pH}$ values of untreated and acid-treated BASHP suspensions were estimated to be 10.14 and 10.93, respectively. Furthermore, the electrical conductivities (EC) of untreated and acid-treated BASHP suspensions were found to be 2155 and $2918 \mu \mathrm{S} / \mathrm{cm}$, respectively. These values are lower than that reported for Miswak-3 $(5040 \mu \mathrm{S} / \mathrm{cm})$, indicating that Miswak-3 solution has a high content of dissolved ions [38]. The $\mathrm{pH}$ at the point of zero charges ( $\mathrm{pH}$ PZC) of acid-treated BASHP was estimated to be 10.73, as shown in Figure 2b. This means that the surface of BASHP will be positively charged below the $\mathrm{pH}$ PZC $(\mathrm{pH}>10.73)$ and negatively charged above the $\mathrm{pH} P \mathrm{PZC}(\mathrm{pH}<10.73)$, promoting, respectively, anionic and cationic dye adsorption. 


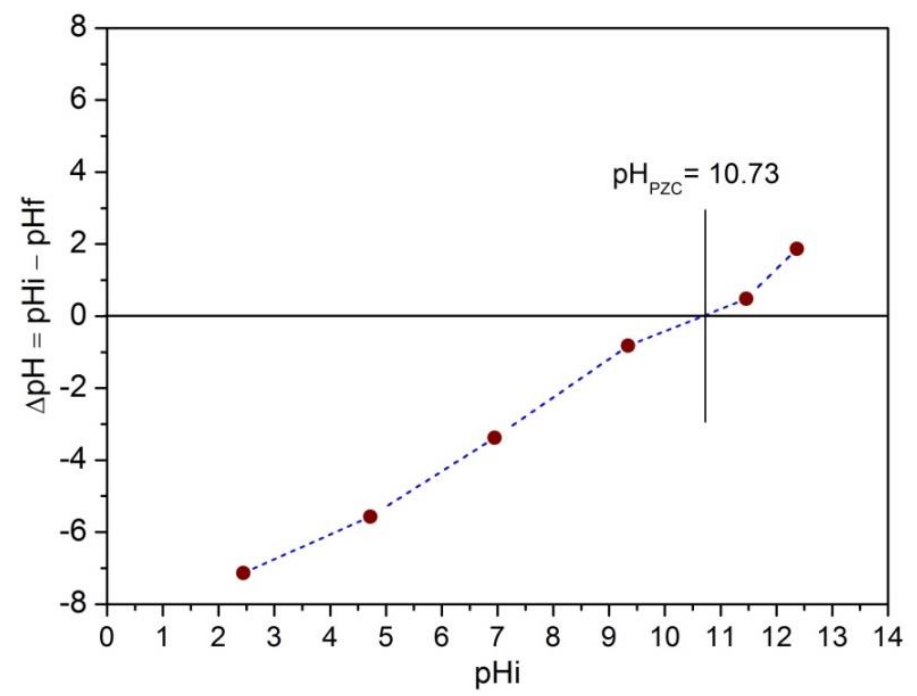

Figure 4. The $\mathrm{pH}$ at the point of zero charges ( $\mathrm{pH}_{\mathrm{PZC}}$ ) of acid-treated BASHP.

\subsection{Factors affecting $M B$ adsorption}

For the sake of comparison, the adsorption of methylene blue (MB) was investigated using untreated and acid-treated BASHP at two different biosorbent dosages $(0.01$ and 0.04 $\mathrm{g} / 20 \mathrm{~mL}$ ), as shown in Figure 5. In this experiment, the MB dye concentration was $100 \mathrm{mg} / \mathrm{L}$, contact time of $1 \mathrm{~h}$, shaking speed of $150 \mathrm{rpm}$, and room temperature. As shown, in both cases, the removal percentage $(\% R)$ of MB using phosphoric acid-treated BASHP was higher than that for untreated BASHP. This could be because the treatment of the BASHP sample with phosphoric acid increased its surface area and porosity, as indicated by its higher iodine number value $(803.27 \mathrm{mg} / \mathrm{g})$ compared to the untreated sample $(174.42 \mathrm{mg} / \mathrm{g})$. Thus, MB removal will be investigated using acid-treated BASHP as bisorbent materials, and the factors affecting the biosorption process are discussed in detail below.

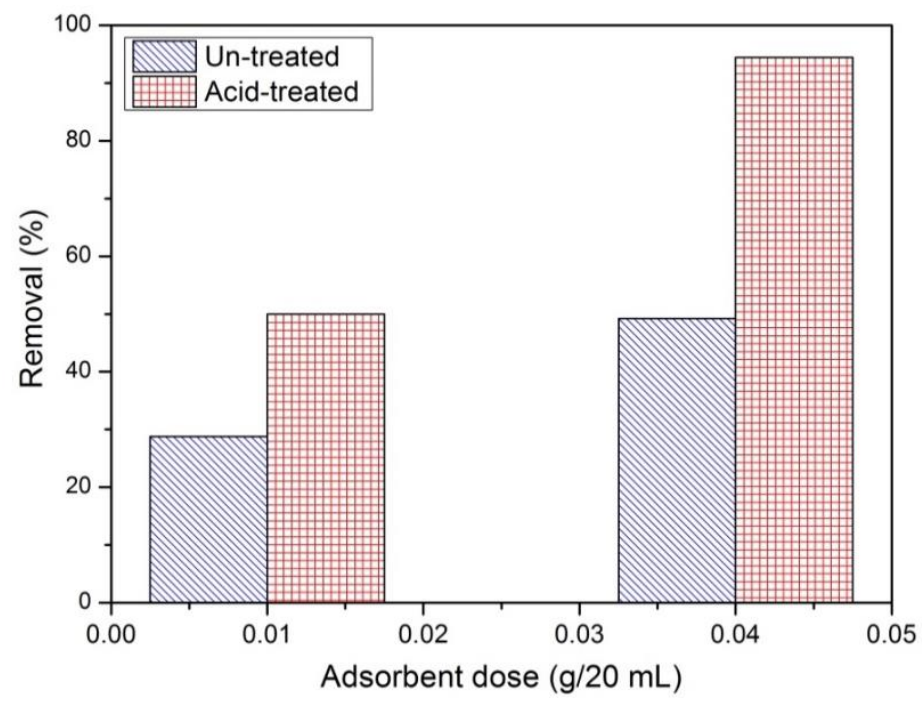

Figure 5. The percentage removal of MB as a function of untreated and acid-treated BASHP.

\subsubsection{Effect of shaking speed.}

The effect of shaking speed on the $\% R$ of MB is shown in Figure 6. In this experiment, the shaking speed was increased from 150 to $300 \mathrm{rpm}$ while the other experimental parameters remained constant (contact time for $1 \mathrm{~h}$, initial concentration at $100 \mathrm{mg} / \mathrm{L}$, biosorbent dosage at $0.04 \mathrm{~g} / 20 \mathrm{~mL}$ ). As shown, increasing the shaking speed from 150 to $300 \mathrm{rpm}$ reduced the 
$\% R$ of MB. This decrease in the $\% R$ values could be attributed to the desorption of some dye molecules from the acid-treated BASHP surface at high shaking speeds [39]. As a result, 150 rpm was chosen as the optimum shaking speed in this study.

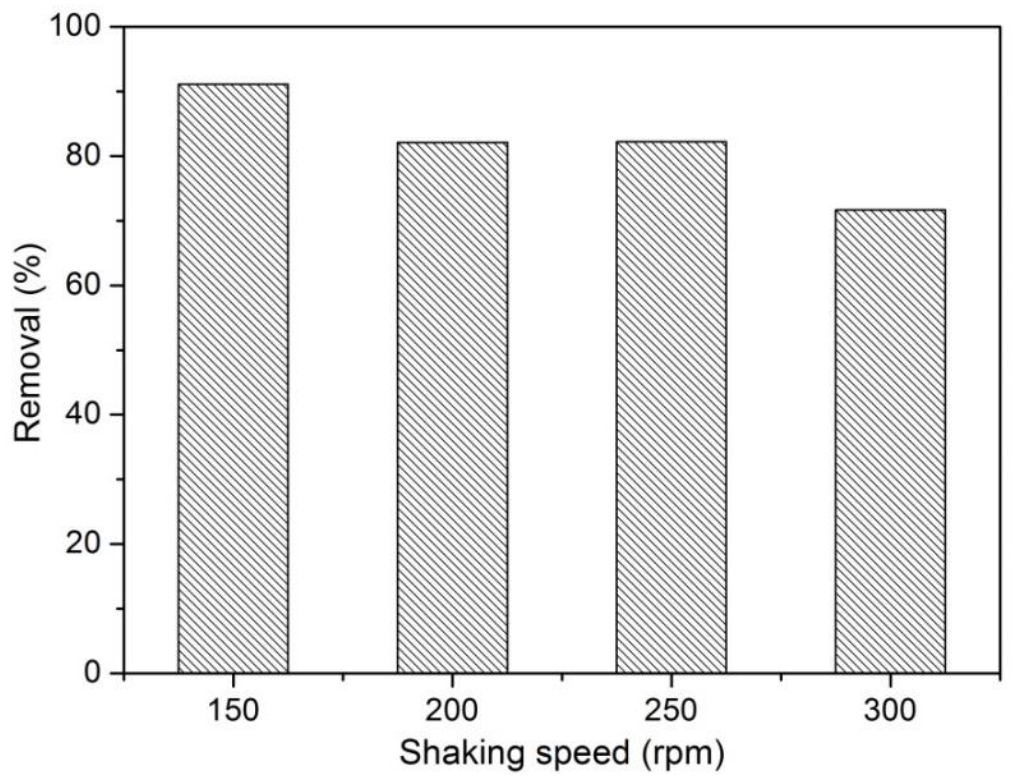

Figure 6. Effect of shaking speed on the removal percentage of MB.

\subsubsection{Effect of contact time.}

Figure 7 depicts the effect of the contact time on the $\% R$ of MB. This effect was investigated over a range of contact times $(0-90 \mathrm{~min})$, biosorbent dosage of $0.04 \mathrm{~g} / 20 \mathrm{~mL}$, shaking speed of $150 \mathrm{rpm}$, and initial MB concentration of $100 \mathrm{mg} / \mathrm{L}$. As shown, within the first 10 minutes of contact, the $\% R$ of $\mathrm{MB}$ reached approximately $87 \%$. This rapid increase in the $\% R$ can be attributed to an abundance of vacant active sites on the biosorbent surface (acidtreated BASHP). However, no significant increase in the $\% R$ value was observed, which could be attributed to MB dye molecules saturating the available active sites on the acid-treated BASHP surface [12]. Furthermore, after 30 min of contact, the maximum $\% R$ value of $90.90 \%$ was obtained. Therefore, $30 \mathrm{~min}$ appears to be the optimum contact time in this study.

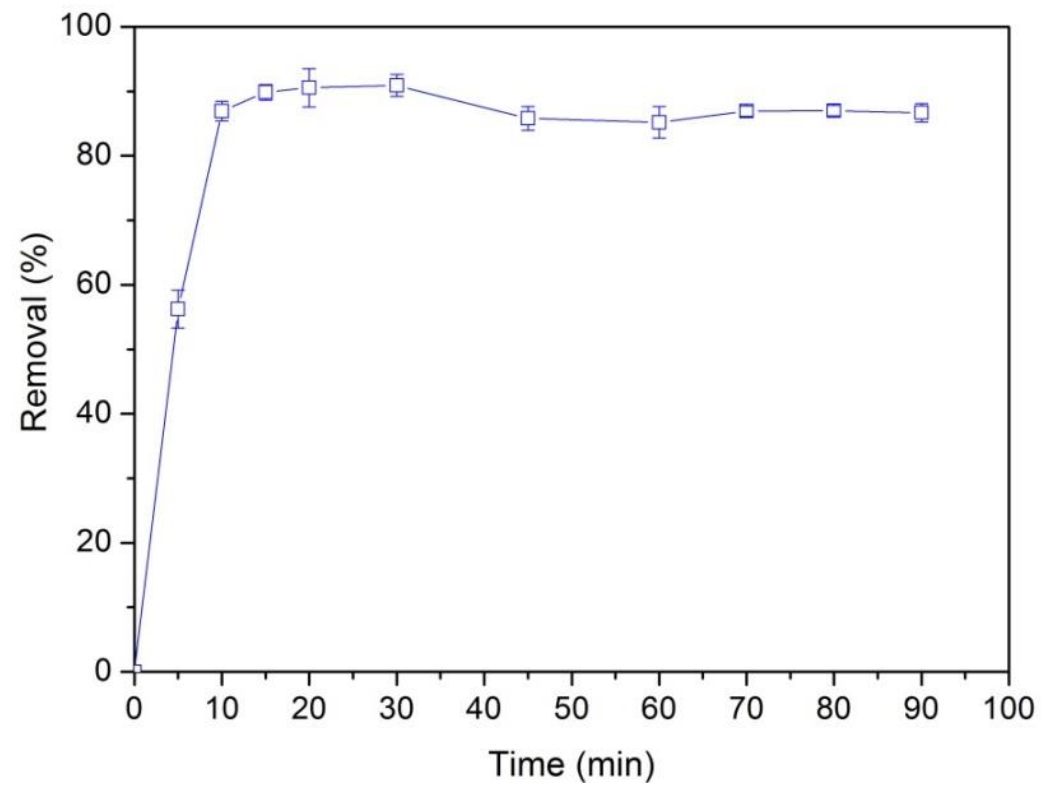

Figure 7. Effect of contact time on the removal percentage of MB. 


\subsubsection{Effect of initial dye concentration.}

Figure 8 depicts the effect of initial dye concentration on the $\% R$ of $\mathrm{MB}$. The effect was studied by increasing the initial MB concentration from 100 to $300 \mathrm{mg} / \mathrm{L}$ while keeping the other conditions constant (shaking speed of $150 \mathrm{rpm}$, contact time of 30 minutes, and biosorbent dosage of $0.04 \mathrm{~g} / 20 \mathrm{~mL}$ ). As shown, the $\% R$ of MB decreased gradually as the initial dye concentration was increased. This could be due to the saturation of available active binding sites on the acid-treated BASHP surface at high initial dye concentrations [36]. Thus, in this study, $100 \mathrm{mg} / \mathrm{L}$ was chosen as the optimal initial MB dye concentration.

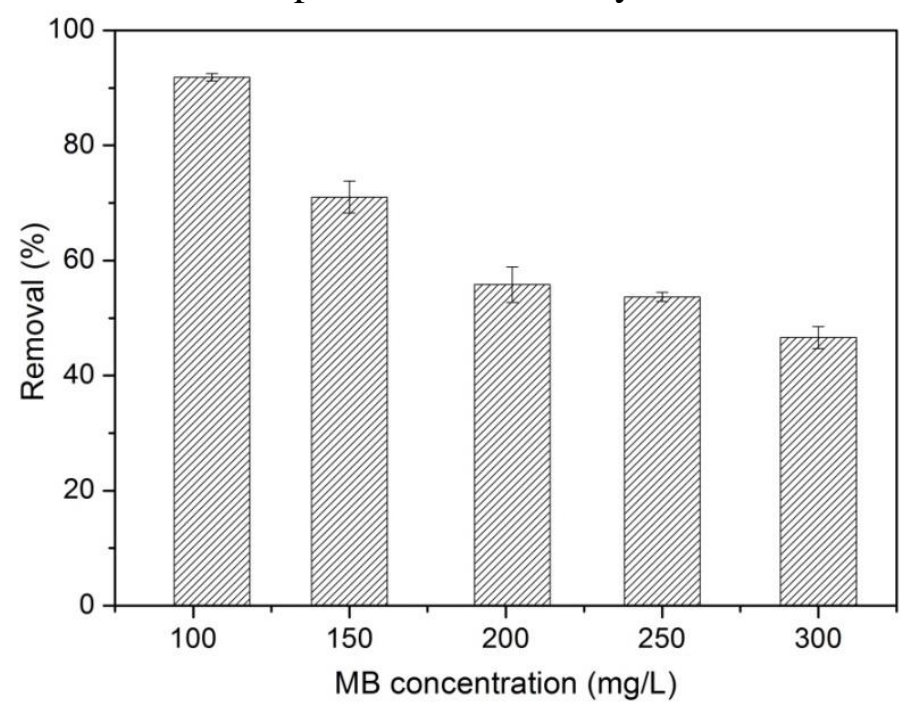

Figure 8. Effect of initial dye concentration on the removal percentage of MB.

\subsubsection{Effect of adsorbent dosage.}

The effect of biosorbent dosage on the $\% R$ and adsorbed amount MB dye $\left(q_{\mathrm{e}}, \mathrm{mg} / \mathrm{g}\right)$ was investigated by varying the acid-treated BASHP amount from 0.02 to $0.12 \mathrm{~g} / 20 \mathrm{~mL}$ while keeping the other conditions constant (contact time at $30 \mathrm{~min}$, shaking speed at $150 \mathrm{rpm}$, and initial dye concertation at $100 \mathrm{mg} / \mathrm{L}$ ), as shown in Figure 9.

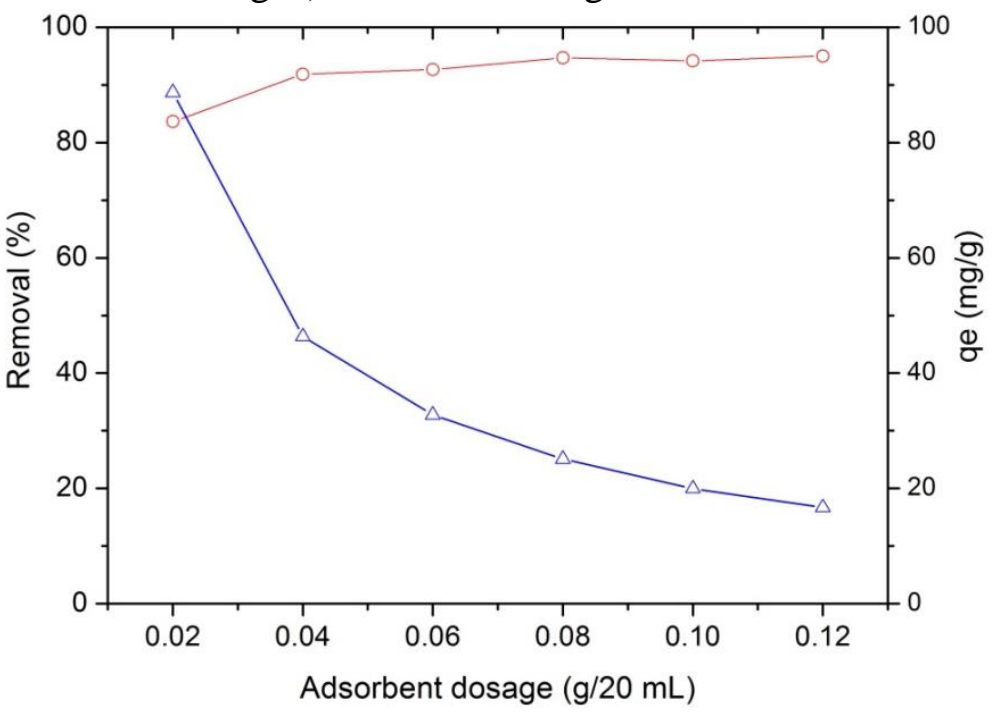

Figure 9. Effect of adsorbent dosage on the removal percentage and adsorbed amount of MB.

As can be seen, increasing the dosage of the adsorbent (acid-treated BASHP) from 0.01 to $0.08 \mathrm{~g} / 20 \mathrm{~mL}$ increased the $\% R$ from 83.64 to $94.70 \%$, respectively. In contrast, increasing the acid-treated BASHP amount from 0.02 to $0.12 \mathrm{~g} / 20 \mathrm{~mL}$ resulted in a significant decrease 
in the adsorbed amount of MB from 88.67 to $16.70 \mathrm{mg} / \mathrm{g}$, respectively. This could be due to a decrease in surface area of the biosorbent as a result of particle aggregation as the biosorbent dosage is increased $[17,36]$.

\subsubsection{Effect of solution $\mathrm{pH}$.}

The effect of solution $\mathrm{pH}$ on the $\% R$ of $\mathrm{MB}$ was studied at different $\mathrm{pH}$ values $(\sim 4$ to 13), shaking speed of $150 \mathrm{rpm}$, contact time of $30 \mathrm{~min}$, and biosorbent dosage of $0.12 \mathrm{~g} / 20 \mathrm{~mL}$, as illustrated in Figure 10. As shown, the $\% R$ of MB increased with increasing the solution $\mathrm{pH}$, reaching a maximum of about $95.38 \%$ at a $\mathrm{pH}$ of 8.38 (lower than $\mathrm{pH}$ PzC), after which the $\% R$ of MB decreased slightly. As previously stated, the $\mathrm{pH}_{\mathrm{PZC}}$ of the biosorbent (acid-treated BASHP) is 10.73. This means that the acid-treated BASHP surface will be positively charged when the $\mathrm{pH}$ is less than 10.73 and negatively charged when the $\mathrm{pH}$ is greater than 10.73 , favoring anionic and cationic dye adsorption, respectively. As a result, at high $\mathrm{pH}$ values (> 10.73), a high $\% R$ of $\mathrm{MB}$ (positively charged ions) was expected. As a result, the slight decrease in $\mathrm{MB} \% R$ at $\mathrm{pH}$ values greater than $10.73\left(\mathrm{pH}_{\mathrm{PZC}}\right)$ can be attributed to the fact that MB contains $\mathrm{Cl}^{-}$and $\mathrm{NaOH}$ used for $\mathrm{pH}$ adjustment will undergo a replacement reaction resulting in the formation of $\mathrm{NaCl}$. As a result, the formed $\mathrm{NaCl}$ increases the ionic strength of $\mathrm{MB}$ dye solution, resulting in a decrease in $\mathrm{MB}$ 's $\% R$ [16].

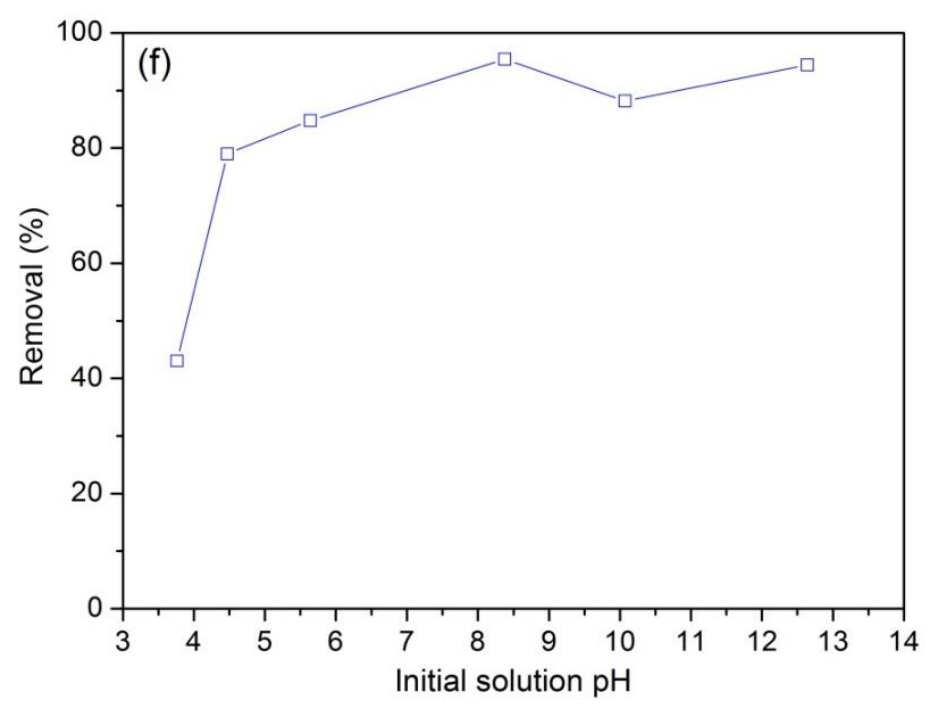

Figure 10. Effect of initial solution $\mathrm{pH}$ on the removal percentage of MB.

\subsubsection{Effect of solution temperature.}

Figure 11 shows the effect of dye solution temperature on the $\% R$ of $\mathrm{MB}$. This effect was investigated by changing the dye solution temperature from 25 to $45^{\circ} \mathrm{C}$ while maintaining the other experimental condition at the previously mentioned optimized conditions. As can be seen, there is a slight increase in the $\% R$ of $\mathrm{MB}$ from 95.54 to $97.44 \%$ with an increase in the solution temperature from 25 to $45^{\circ} \mathrm{C}$, respectively. This increase in $\% R$ of $\mathrm{MB}$ with increasing solution temperature implies that the biosorption of $\mathrm{MB}$ molecules onto the acid-treated BASHP surface is an endothermic process [40]. 


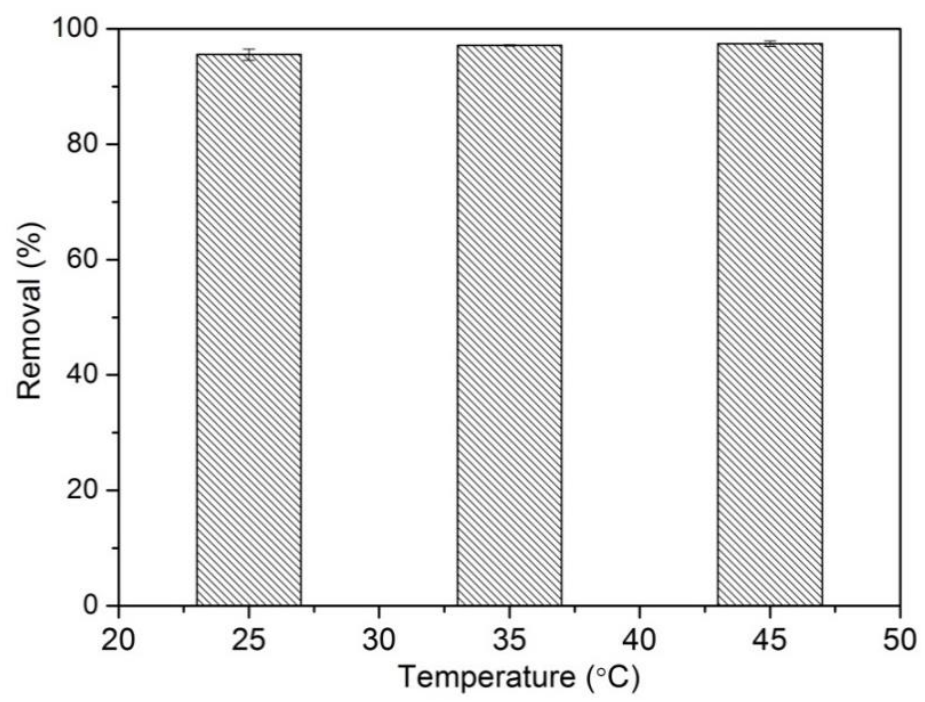

Figure 11. Effect of solution temperature on the removal percentage of MB.

\subsubsection{Effect of ionic strength.}

Figure 12 depicts the effect of solution ionic strength on MB $\% R$. In this experiment, the $\mathrm{NaCl}$ solution concentration was changed from 0 to $0.8 \mathrm{~mol} / \mathrm{L}$ while the other experimental conditions remained at the previously mentioned optimal values. As shown, the $\% R$ of $\mathrm{MB}$ decreased gradually with increasing $\mathrm{NaCl}$ concentration, reaching its lowest value $(27.7 \%)$ when $\mathrm{NaCl}$ was $0.8 \mathrm{~mol} / \mathrm{L}$. This decrease in $\mathrm{MB} \% R$ is due to an increase in solution ionic strength, which resulted in high competition between positively charged MB molecules and $\mathrm{Na}^{+}$ions for available active bidding sites on the surface of acid-treated BASHP (negatively charged) [36]. This phenomenon was also observed during the study of the initial solution $\mathrm{pH}$ effect, as mentioned above.

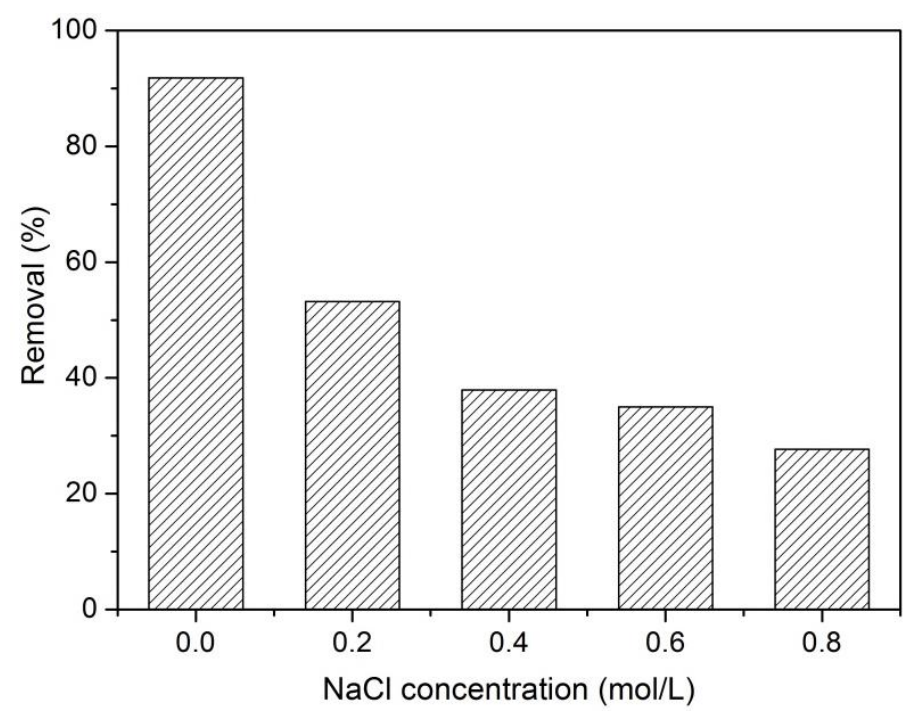

Figure 12. Effect ionic strength on the removal percentage of MB.

\subsection{Adsorption kinetics.}

Table 1 lists the estimated parameters for pseudo-first-order, PFO (Figure 13a) and pseudo-second-order, PSO (Figure 13b) kinetic models. According to the correlation coefficient (R2) value, the PSO with the highest $R^{2}$ value $(0.9985)$ best describes the biosorption kinetics. Furthermore, when compared to the PFO kinetic model, the calculated adsorbed amount ( $q_{\mathrm{e}}, \mathrm{cal}, \mathrm{mg} / \mathrm{g}$ ) of MB derived from PSO is much closer to the experimental 
one $\left(q_{\mathrm{e}}\right.$, exp, $\left.\mathrm{mg} / \mathrm{g}\right)$, indicating that the PSO kinetic model for MB dye biosorption onto acidtreated BABP. The fact that the experimental adsorption data fit the pseudo-second-order model well implies that the adsorption mechanism is dependent on both adsorbate and adsorbent material properties [41].
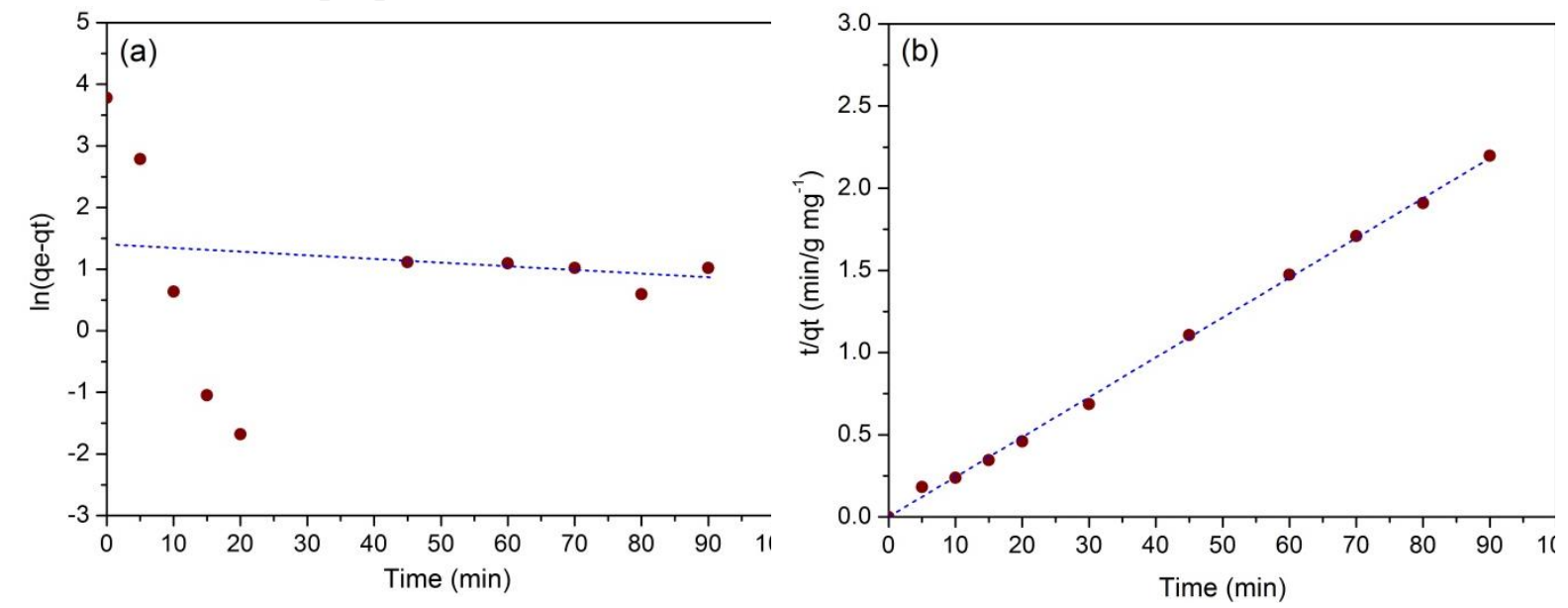

Figure 13. Kinetic models. (a) pseudo-first-order; (b) pseudo-second-order.

Table 1. Kinetic models parameters for MB biosorption on acid-treated BASHP.

\begin{tabular}{c|c|c|c}
$\left(q_{\mathrm{e}, \text { exp }}\right)$ & \multicolumn{3}{|c}{ Pseudo-first-order } \\
\cline { 2 - 4 }$(\mathrm{mg} / \mathrm{g})$ & $\left(q_{\mathrm{e}, \mathrm{cal}}\right)(\mathrm{mg} / \mathrm{g})$ & $k_{1}\left(\mathrm{~min}^{-1}\right)$ & $R^{2}$ \\
\hline \multirow{3}{*}{43.71} & 4.05 & $6.2 \times 10^{-3}$ & 0.0095 \\
\cline { 2 - 4 } & & $k_{2}(\mathrm{~g} / \mathrm{mg} \cdot \mathrm{min})$ & $R^{2}$ \\
\cline { 2 - 4 } & $\left(q_{\mathrm{e}, \mathrm{cal}}\right)(\mathrm{mg} / \mathrm{g})$ & $5.76 \times 10^{-1}$ & 0.9985
\end{tabular}

\subsection{Adsorption isotherm.}

The estimated parameters for the Langmuir and Freundlich isotherms are listed in Table 2. According to the table, the Langmuir isotherm model (Figure 14a) fits the experimental data points better $\left(R^{2}=0.9626\right)$ than the Freundlich (Figure $\left.14 \mathrm{~b}\right)$ isotherm $\left(R^{2}=0.6991\right)$. This demonstrates that the Langmuir isotherm model is more applicable to describe the proposed biosorption process. Besides, the monolayer biosorption capacity $\left(q_{\max }\right)$ of MB molecules onto the prepared biosorbent material (acid-treated BASHP) was approximately $72.99 \mathrm{mg} / \mathrm{g}$. The Langmuir model's suitability was further assessed by calculating the values separation factor $\left(R_{\mathrm{L}}\right)$, the results of which are plotted in Figure 14c. Furthermore, within the dye concentration range (100-300 mg/L), the estimated $R_{\mathrm{L}}$ values were found to be less than unity $(0.58-0.33)$, indicating the suitability of the proposed biosorption process [13]. Table 4 compares the maximum absorbed amount of $\mathrm{MB}$ dye $\left(q_{\max }, \mathrm{mg} / \mathrm{g}\right)$ or adsorption capacities of various adsorbents to acid-treated BASHP. As shown in the table, the maximum absorbed amount of $\mathrm{MB}$ onto the proposed biosorbent (acid-treated BASHP) was lower, higher or comparable to those reported for the listed biosorbents. Adsorption capacities can differ due to adsorbent properties (such as surface area, porosity, and functional groups) or experimental adsorption conditions (e.g., initial $\mathrm{pH}$ and solution temperature). According to the findings, the proposed material (acid-treated BASHP) is a promising low-cost, readily available, and environmentally friendly biosorbent. Furthermore, the adsorption efficiency of acid-treated BASHP could be increased further by converting it to low-cost derived activated carbon. 

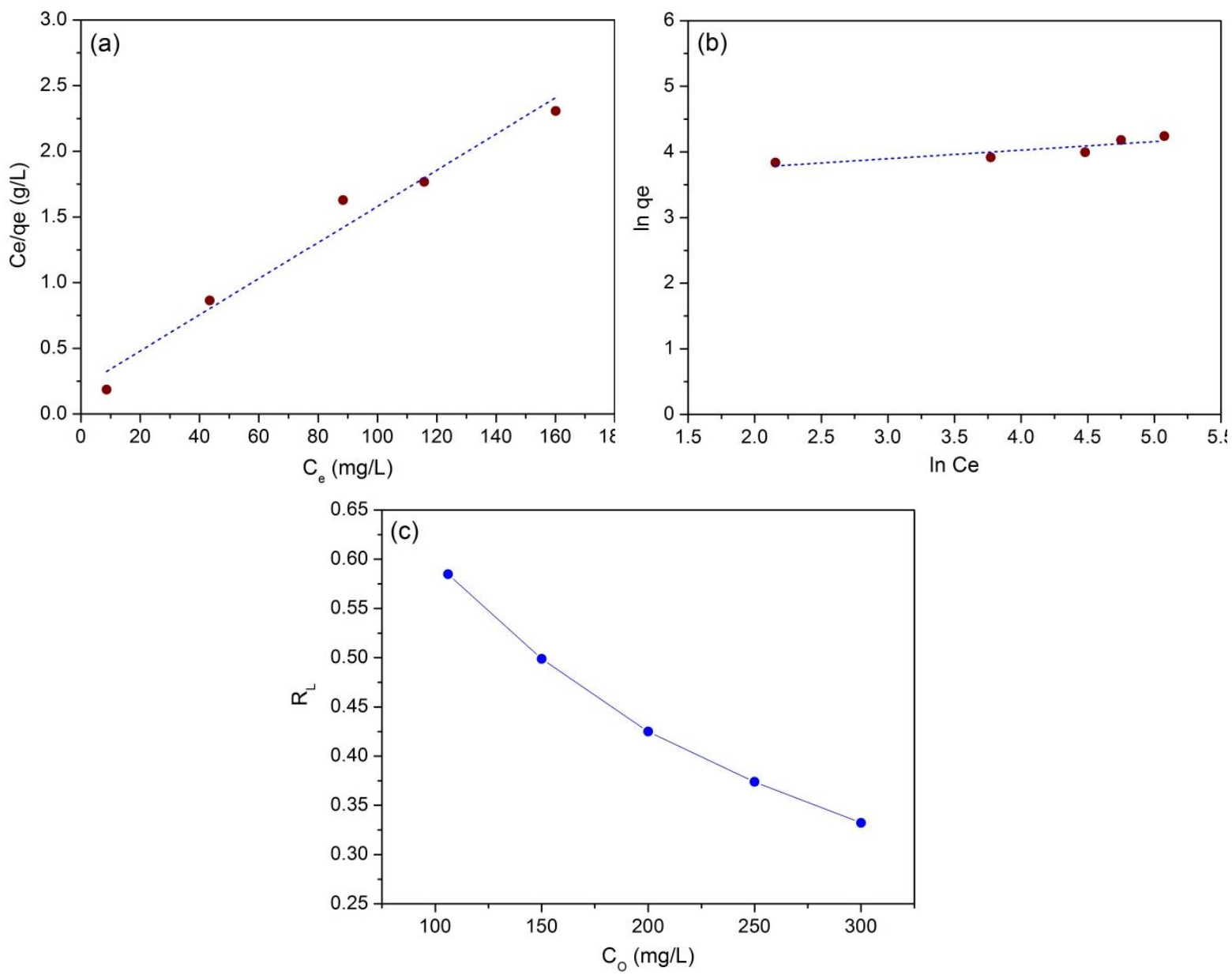

Figure 14. (a) Langmuir isotherm; (b) Frendulich isotherm; (c) separation factor.

Table 2. Isotherm models parameters for MB biosorption onto acid-treated BASHP. Langmuir isotherm

\begin{tabular}{cc|c|c}
\hline \multicolumn{2}{c|}{$R^{2}$} & $K_{\mathrm{L}}(\mathrm{L} / \mathrm{mg})$ & $q_{\max }(\mathrm{mg} / \mathrm{g})$ \\
\hline \multicolumn{2}{c|}{0.9626} & $6.70 \times 10^{-2}$ & 72.99 \\
\hline \multicolumn{5}{c}{ Freundlich isotherm } \\
\hline$R^{2}$ & $n$ & $1 / n$ & $K_{\mathrm{F}}\left(\mathrm{mg} / \mathrm{g}(\mathrm{L} / \mathrm{mg})^{1 / \mathrm{n}}\right)$ \\
\hline 0.6991 & 7.67 & 0.1304 & 33.31
\end{tabular}

Table 3. The maximum adsorbent amount $\left(\boldsymbol{q}_{\max }, \mathbf{m g} / \mathbf{g}\right)$ of MB using various biosorbents.

\begin{tabular}{c|c|c} 
Adsorbent & $\mathbf{q}_{\mathbf{m a x}}(\mathbf{m g} / \mathbf{g})$ & Reference \\
\hline Ficcus palmata leaves (FPL) & 6.89 & {$[42]$} \\
\hline $\mathrm{NaOH}$-activated banana peels (BP) & 19.67 & {$[43]$} \\
\hline Carica papaya wood (CPW) & 32.25 & {$[36]$} \\
\hline Casuarina equisetifolia pines (CeP) & 41.35 & {$[44]$} \\
\hline $\mathrm{H}_{2} \mathrm{SO}_{4}$ functionalized Casuarina equisetifolia pine & 42.19 & {$[45]$} \\
\hline Salix babylonica $(\mathrm{SB})$ & 42.74 & {$[10]$} \\
\hline Potato leaves powder (PLP) & 52.6 & {$[46]$} \\
\hline $\mathrm{H}_{3} \mathrm{PO}_{4}$-treated Balanites aegyptiaca seed husks powder (acid- & 72.99 & This study \\
\hline treated BASHP) & & {$[47]$} \\
\hline Cyanthilium cinereum (L.) H. Rob (CCLHR) & 76.34 & {$[11]$} \\
\hline Terminalia catappa (TC) shell & 88.62 & {$[48]$} \\
\hline $\mathrm{H}_{2} \mathrm{O}_{2}$-activated Durian peel (DP) & 90.9 & {$[49]$} \\
\hline Fava bean peel (FBP) & 140 & {$[50]$} \\
\hline $\mathrm{H}_{3} \mathrm{PO}_{4}$-treated Oreganum Stalks (OS-P) & 147.06 & {$[16]$}
\end{tabular}




\subsection{Thermodynamic analysis.}

Equations 9 to 11 were used to estimate the values of thermodynamic parameters $\left(\Delta G^{0}\right.$, $\Delta H^{\circ}, \Delta H^{\circ}$ ) for MB biosorption onto acid-treated BASHP, and the results are listed in Table 4. The negative $\Delta G^{\mathrm{o}}$ values indicate the spontaneous nature and energy feasibility of the proposed process. The positive value of $\Delta H^{0}$ implies that biosortpion of $\mathrm{MB}$ onto the surface of acidtreated BASHP is an endothermic process. Furthermore, the low value of $\Delta H^{\mathrm{o}}(25.76 \mathrm{~kJ} / \mathrm{mol})$ was less than $40 \mathrm{~kJ} / \mathrm{mol}$ indicates that $\mathrm{MB}$ adsorption occurs via physical adsorption mechanism [51]. The positive $\Delta S^{0}$ value $(112.27 \mathrm{~J} / \mathrm{mol} . \mathrm{K})$ implies an increase in disorder at the interfacial region between two phases (solid and liquid) [52].

Table 4. Thermodynamic parameters for MB biosorption onto acid-treated BASHP.

\begin{tabular}{|c|c|c|c|c|}
\hline $\begin{array}{c}\boldsymbol{T} \\
(\mathrm{K})\end{array}$ & $\begin{array}{c}\Delta \boldsymbol{G}^{\mathbf{o}} \\
(\mathrm{kJ} / \mathrm{mol})\end{array}$ & $\begin{array}{c}\boldsymbol{T} \Delta \boldsymbol{S}^{\mathbf{o}} \\
(\mathrm{kJ} / \mathrm{mol})\end{array}$ & $\begin{array}{c}\Delta \boldsymbol{H}^{\mathbf{o}} \\
(\mathrm{kJ} / \mathrm{mol})\end{array}$ & $\underset{(\mathrm{J} / \mathrm{mol} . \mathrm{K})}{\Delta \boldsymbol{S}^{\mathbf{o}}}$ \\
\hline 298 & -8.46 & 33.46 & \multirow[t]{3}{*}{25.76} & \multirow[t]{3}{*}{112.27} \\
\hline 308 & -8.82 & 34.58 & & \\
\hline 318 & -9.94 & 35.70 & & \\
\hline
\end{tabular}

3.6. Desorption study.

This study investigated acid-treated BASHP reusability for MB removal from the aquatic environment for three cycles using an eluent composed of ethanol and acetic acid solution (96:4 V/V\%), as shown in Figure 15. As can be seen, the $\% R$ of MB decreases gradually from $95.56 \%$ at the initial adsorptive removal experiment to $24.66 \%$ after the third cycle. The $\% R$ decrease of MB could be because active binding sites on the biosorbent surface (acid-treated BASHP) have been lost or obstructed [53].

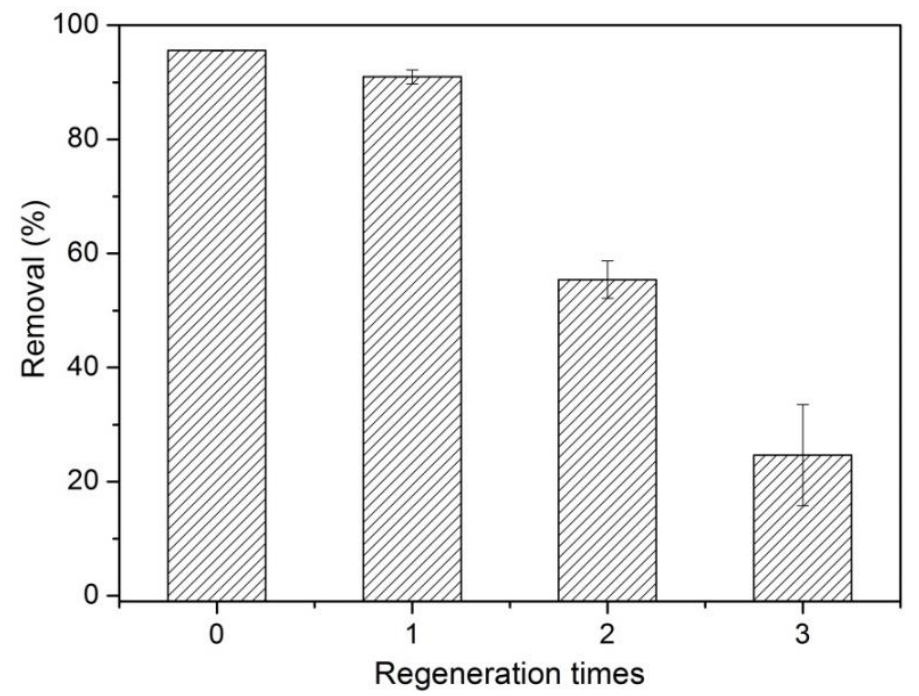

Figure 15. Desorption efficiency of BASHP biosorbent for MB.

\section{Conclusions}

In summary, the adsorption properties of non-carbonized phosphoric acid-treated Balanites aegyptiaca "heglig" seed husks powder (acid-treated BASHP) for removing methylene blue dye (MB) from aqueous solutions were investigated successfully. The biosorbent's $\mathrm{pH}$ at the point of zero charges ( $\mathrm{pH}$ PZC), iodine number, and specific surface area $\left(S_{\mathrm{MB}}\right)$ were determined to be $10.73,803.27 \mathrm{mg} / \mathrm{g}$, and $271.04 \mathrm{~m}^{2} / \mathrm{g}$, respectively. The batch mode was chosen to investigate the biosorption of MB onto the acid-treated BASHP surface, and under optimal conditions, more than $97 \%$ of the MB was removed. The results showed that 
pseudo-second-order better described the adsorption kinetics, whereas the Langmuir model described the biosorption isotherm better. The maximum amount of MB biosorbed onto the acid-treated BASHP surface was approximately $72.99 \mathrm{mg} / \mathrm{g}$. According to the thermodynamic parameters $\left(\Delta G^{\mathbf{0}}, \Delta H^{\mathbf{0}}, \Delta S^{\mathbf{0}}\right)$, the biosorption of MB dye molecules onto the acid-treated BASHP surface is a spontaneous and endothermic process. According to the findings, acidtreated BASHP can be regarded as a promising, low-cost, eco-friendly, and widely available biosorbent material for removing water pollutants such as highly toxic dyes (e.g., methylene blue). The current study also suggests a promising method for reducing agricultural solid waste.

\section{Funding}

This research received no external funding.

\section{Acknowledgments}

The authors would like to express their gratitude to the Chemistry Department at Sebha University in Sebha, Libya, for providing the necessary facilities for this research. The authors would also like to express their gratitude to the Criminal Investigation Department, Sabha City Branch, for providing the FTIR instrument.

\section{Conflicts of Interest}

The authors declare no conflict of interest.

\section{References}

1. Srivastava, R.; Rupainwar, D.C. Liquid phase adsorption of Indigo Carmine and Methylene Blue on Neem bark. Desalination and Water Treatment 2010, 24, 74-84, https://doi.org/10.5004/dwt.2010.1195.

2. A.G, E.-S.; A.M, G.; Mansour, H.F. Potential application of orange peel as an eco-friendly adsorbent for textile dyeing effluents. Research Journal of Textile and Apparel 2013, 17, 31-39, https://doi.org/10.1108/rjta-17-04-2013-b004.

3. Rafatullah, M.; Sulaiman, O.; Hashim, R.; Ahmad, A. Adsorption of methylene blue on low-cost adsorbents: A review. Journal of Hazardous Materials 2010, 177, 70-80, https://doi.org/10.1016/j.jhazmat.2009.12.047.

4. Ighalo, J.O.; Adeniyi, A.G. Adsorption of pollutants by plant bark derived adsorbents: An empirical review. Journal of Water Process Engineering 2020, 35, 101228, https://doi.org/10.1016/j.jwpe.2020.101228.

5. Hu, N.; Zhang, K.; Zhao, Y.; Zhang, Z.; Li, H. Flotation-based dye removal system: Sweet potato protein fabricated from agro-industrial waste as a collector and frother. Journal of Cleaner Production 2020, 269, 122121, https://doi.org/10.1016/j.jclepro.2020.122121.

6. Gnanasekaran, G.; Sudhakaran, M.S.P.; Kulmatova, D.; Han, J.; Arthanareeswaran, G.; Jwa, E.; Mok, Y.S. Efficient removal of anionic, cationic textile dyes and salt mixture using a novel CS/MIL-100 (Fe) based nanofiltration membrane. Chemosphere $2021, \quad 284, \quad 131244$, https://doi.org/10.1016/j.chemosphere.2021.131244.

7. Januário, E.F.D.; Vidovix, T.B.; Bergamasco, R.; Vieira, A.M.S. Performance of a hybrid coagulation/flocculation process followed by modified microfiltration membranes for the removal of solophenyl blue dye. Chemical Engineering and Processing - Process Intensification 2021, 168, 108577, https://doi.org/10.1016/j.cep.2021.108577.

8. Rodríguez-Narváez, O.M.; Picos, A.R.; Bravo-Yumi, N.; Pacheco-Alvarez, M.; Martínez-Huitle, C.A.; Peralta-Hernández, J.M. Electrochemical oxidation technology to treat textile wastewaters. Current Opinion in Electrochemistry 2021, 29, 100806, https://doi.org/10.1016/j.coelec.2021.100806.

9. Amar, I.A.; Harara, H.M.; Baqul, Q.A.; Abdul Qadir, M.A.; Altohami, F.A.; Ahwidi, M.M.; Abdalsamed, I.A.; Saleh, F.A. Photocatalytic degradation of malachite green dye under UV light irradiation using calciumdoped ceria nanoparticles. Asian Journal of Nanosciences and Materials 2020, 3, 1-14, https://doi.org/10.26655/AJNANOMAT.2020.1.1. 
10. Gemici, B.T.; Ozel, H.U.; Ozel, H.B. Removal of methylene blue onto forest wastes: Adsorption isotherms, kinetics and thermodynamic analysis. Environmental Technology \& Innovation 2021, 22, 101501, https://doi.org/10.1016/j.eti.2021.101501.

11. Hevira, L.; Zilfa; Rahmayeni; Ighalo, J.O.; Aziz, H.; Zein, R. Terminalia catappa shell as low-cost biosorbent for the removal of methylene blue from aqueous solutions. Journal of Industrial and Engineering Chemistry 2021, 97, 188-199, https://doi.org/10.1016/j.jiec.2021.01.028.

12. Felista, M.M.; Wanyonyi, W.C.; Ongera, G. Adsorption of anionic dye (Reactive black 5) using macadamia seed Husks: Kinetics and equilibrium studies. Scientific African 2020, 7, e00283, https://doi.org/10.1016/j.sciaf.2020.e00283.

13. Lim, L.B.L.; Priyanth, N.; Tennakoon, D.T.B.; Chieng, H.I.; Dahri, M.K.; Suklueng, M. Breadnut peel as a highly effective low-cost biosorbent for methylene blue: Equilibrium, thermodynamic and kinetic studies. Arabian Journal of Chemistry 2017, 10, S3216-S3228, https://dx.doi.org/10.1016/j.arabjc.2013.12.018.

14. Ramírez Calderón, O.A.; Abdeldayem, O.M.; Pugazhendhi, A.; Rene, E.R. Current Updates and Perspectives of Biosorption Technology: an Alternative for the Removal of Heavy Metals from Wastewater. Current Pollution Reports 2020, 6, 8-27, https://doi.org/10.1007/s40726-020-00135-7.

15. Ansari, S.A.; Khan, F.; Ahmad, A. Cauliflower leave, an agricultural waste biomass adsorbent, and its application for the removal of MB dye from aqueous solution: Equilibrium, kinetics, and thermodynamic studies. International journal of analytical chemistry 2016, https://doi.org/10.1155/2016/8252354.

16. Al-Anber, Z.A.; Al-Anber, M.A.; Matouq, M.; Al-Ayed, O.; Omari, N.M. Defatted Jojoba for the removal of methylene blue from aqueous solution: Thermodynamic and kinetic studies. Desalination 2011, 276, 169174, https://doi.org/10.1016/j.desal.2011.03.043.

17. Hassan, W.; Farooq, U.; Ahmad, M.; Athar, M.; Khan, M.A. Potential biosorbent, Haloxylon recurvum plant stems, for the removal of methylene blue dye. Arabian Journal of Chemistry 2017, 10, S1512-S1522, https://doi.org/10.1016/j.arabjc.2013.05.002.

18. Chothani, D.L.; Vaghasiya, H.U. A review on Balanites aegyptiaca Del (desert date): phytochemical constituents, traditional uses, and pharmacological activity. Pharmacogn Rev 2011, 5, 55-62, https://doi.org/10.4103/0973-7847.79100.

19. Magaji, B.; Maigari, A.U.; Abubakar, U.A.; Sani, M.M.; Maigari, A.U. Batch Adsorption of Safranin Dye from an Aqueous Solution of Balanites aegyptiaca Seed Coats. Asian Journal of Physical and Chemical Sciences 2020, 8, 48-54, https://doi.org/10.9734/ajopacs/2020/v8i130109.

20. Massai, H.; Nlondok, L.; Tcheka, C.; Loura, B.; Nistor, I.D.; Ketcha, J. Kinetic and batch equilibrium adsorption of nickel (II) and copper (II) ions from aqueous solution on to activated carbon prepared from Balanites aegyptiaca shells. American Chemical Science Journal 2015, 6, 38-50, https://doi.org/10.9734/ACSJ/2015/14514.

21. Al Bahri, M.; Calvo, L.; Gilarranz, M.A.; Rodriguez, J.J. Activated carbon from grape seeds upon chemical activation with phosphoric acid: Application to the adsorption of diuron from water. Chemical Engineering Journal 2012, 203, 348-356, https://doi.org/10.1016/j.cej.2012.07.053.

22. Tran, H.N.; Wang, Y.-F.; You, S.-J.; Chao, H.-P. Insights into the mechanism of cationic dye adsorption on activated charcoal: The importance of $\pi-\pi$ interactions. Process Safety and Environmental Protection 2017, 107, 168-180, https://doi.org/10.1016/j.psep.2017.02.010.

23. ASTM, D. Standard test method for $\mathrm{pH}$ of activated carbon. ASTM Standard 1999, 15, 1-3.

24. Doboy, E.K.; Adjia, H.Z.; Kamga, R.; Lorraine, F. Production and Characterization of Rice Husk Biosorbent from Far North Cameroon. Environment and Pollution 2019, 8, 1-7, https://doi.org/10.5539/ep.v8n2p1.

25. Ekpete, O.A.; Marcus, A.C.; Osi, V. Preparation and characterization of activated carbon obtained from plantain (Musa paradisiaca) fruit Stem. Journal of Chemistry 2017, 2017, 8635615, https://doi.org/10.1155/2017/8635615.

26. Hashem, A.; Elhmmali, M.M. Modification of sodium slginate for the removal of Cd(II) from aqueous solutions. Polymer-Plastics Technology and Engineering 2006, 45, 707-712, https://doi.org/10.1080/03602550600609648.

27. Hu, Y.; Zhang, Y.; Hu, Y.; Chu, C.-Y.; Lin, J.; Gao, S.; Lin, D.; Lu, J.; Xiang, P.; Ko, T.-H. Application of wasted Oolong tea as a biosorbent for the adsorption of methylene blue. Journal of Chemistry 2019, 2019, 4980965, https://doi.org/10.1155/2019/4980965.

28. Ho, Y.S.; McKay, G. Pseudo-second order model for sorption processes. Process Biochemistry 1999, 34, 451-465, https://doi.org/10.1016/S0032-9592(98)00112-5. 
29. Dahri, M.K.; Kooh, M.R.R.; Lim, L.B.L. Application of casuarina equisetifolia needle for the removal of methylene blue and malachite green dyes from aqueous solution. Alexandria Engineering Journal 2015, 54, 1253-1263, https://doi.org/10.1016/j.aej.2015.07.005.

30. Tran, H.N.; You, S.-J.; Hosseini-Bandegharaei, A.; Chao, H.-P. Mistakes and inconsistencies regarding adsorption of contaminants from aqueous solutions: A critical review. Water Research 2017, 120, 88-116, https://doi.org/10.1016/j.watres.2017.04.014.

31. Hameed, B.H.; Mahmoud, D.K.; Ahmad, A.L. Equilibrium modeling and kinetic studies on the adsorption of basic dye by a low-cost adsorbent: Coconut (Cocos nucifera) bunch waste. Journal of Hazardous Materials 2008, 158, 65-72, https://doi.org/10.1016/j.jhazmat.2008.01.034.

32. Dinh, V.-P.; Huynh, T.-D.-T.; Le, H.M.; Nguyen, V.-D.; Dao, V.-A.; Hung, N.Q.; Tuyen, L.A.; Lee, S.; Yi, J.; Nguyen, T.D.; et al. Insight into the adsorption mechanisms of methylene blue and chromium(iii) from aqueous solution onto pomelo fruit peel. RSC Advances 2019, 9, 25847-25860, https://doi.org/10.1039/c9ra04296b.

33. Asif Tahir, M.; Bhatti, H.N.; Iqbal, M. Solar Red and Brittle Blue direct dyes adsorption onto Eucalyptus angophoroides bark: Equilibrium, kinetics and thermodynamic studies. Journal of Environmental Chemical Engineering 2016, 4, 2431-2439, https://doi.org/10.1016/j.jece.2016.04.020.

34. Khan, M.A.; Alam, M.M.; Naushad, M.; Alothman, Z.A.; Kumar, M.; Ahamad, T. Sol-gel assisted synthesis of porous nano-crystalline $\mathrm{CoFe}_{2} \mathrm{O}_{4}$ composite and its application in the removal of brilliant blue-R from aqueous phase: An ecofriendly and economical approach. Chemical Engineering Journal 2015, 279, 416424, https://doi.org/10.1016/j.cej.2015.05.042.

35. Cui, L.; Liu, C.; Wu, G. Performance and mechanism of methylene blue biosorption on orange peel. Environmental Technology 2008, 29, 1021-1030, https://doi.org/10.1080/00207210802166872.

36. Rangabhashiyam, S.; Sujata, L.; Balasubramanian, P. Biosorption characteristics of methylene blue and malachite green from simulated wastewater onto Carica papaya wood biosorbent. Surfaces and Interfaces 2018, 10, 197-215, https://doi.org/10.1016/j.surfin.2017.09.011.

37. Association, A.W.W. Standards for granular activated carbons, American Water Works Association. Denver Co., ANSI/AWWA, ppB604-90 1991.

38. Moawed, E.A. Effect of heating processes on Salvadora persica (Miswak) and its application for removal and determination of aniline blue from wastewater. Journal of Taibah University for Science 2013, 7, 26-34, https://doi.org/10.1016/j.jtusci.2013.03.002.

39. Zafar, M.N.; Dar, Q.; Nawaz, F.; Zafar, M.N.; Iqbal, M.; Nazar, M.F. Effective adsorptive removal of azo dyes over spherical ZnO nanoparticles. Journal of Materials Research and Technology 2019, 8, 713-725, https://doi.org/10.1016/j.jmrt.2018.06.002.

40. Amar, I.A.; Asser, J.O.; Mady, A.S.; Abdulqadir, M.S.; Altohami, F.A.; Sharif, A.A.; Abdalsamed, I.A. Adsorptive removal of congo red dye from aqueous solutions using Mo-doped $\mathrm{CoFe}_{2} \mathrm{O}_{4}$ magnetic nanoparticles. Pigment \& Resin Technology 2021, ahead-of-print, https://doi.org/10.1108/prt-02-2020-0016.

41. Wang, L.; Li, J.; Wang, Y.; Zhao, L.; Jiang, Q. Adsorption capability for Congo red on nanocrystalline $\mathrm{MFe}_{2} \mathrm{O}_{4}(\mathrm{M}=\mathrm{Mn}, \mathrm{Fe}, \mathrm{Co}, \mathrm{Ni})$ spinel ferrites. Chemical Engineering Journal 2012, 181-182, 72-79, https://doi.org/10.1016/j.cej.2011.10.088.

42. Fiaz, R.; Hafeez, M.; Mahmood, R. Ficcus palmata leaves as a low-cost biosorbent for methylene blue: Thermodynamic and kinetic studies. Water Environment Research 2019, 91, 689-699, https://doi.org/10.1002/wer.1093.

43. Amela, K.; Hassen, M.A.; Kerroum, D. Isotherm and kinetics study of biosorption of cationic dye onto banana peel. Energy Procedia 2012, 19, 286-295, https://doi.org/10.1016/j.egypro.2012.05.208.

44. Chandarana, H.; Senthil Kumar, P.; Seenuvasan, M.; Anil Kumar, M. Kinetics, equilibrium and thermodynamic investigations of methylene blue dye removal using Casuarina equisetifolia pines. Chemosphere 2021, 285, 131480, https://doi.org/10.1016/j.chemosphere.2021.131480.

45. Chandarana, H.; Suganya, S.; Madhava, A.K. Surface functionalized Casuarina equisetifolia pine powder for the removal of hetero-polyaromatic dye: characteristics and adsorption. International Journal of Environmental Analytical Chemistry 2020, 1-15, https://doi.org/10.1080/03067319.2020.1798418.

46. Gupta, N.; Kushwaha, A.K.; Chattopadhyaya, M.C. Application of potato (Solanum tuberosum) plant wastes for the removal of methylene blue and malachite green dye from aqueous solution. Arabian Journal of Chemistry 2016, 9, S707-S716, https://doi.org/10.1016/j.arabjc.2011.07.021. 
47. Silva, F.; Nascimento, L.; Brito, M.; da Silva, K.; Paschoal, W., Jr.; Fujiyama, R. Biosorption of methylene blue dye using natural biosorbents made from weeds. Materials (Basel) 2019, 12, 2486, https://doi.org/10.3390/ma12152486.

48. Sudrajat, H.; Susanti, A.; Putri, D.K.Y.; Hartuti, S. Mechanistic insights into the adsorption of methylene blue by particulate durian peel waste in water. Water Science and Technology 2021, https://doi.org/10.2166/wst.2021.361.

49. Bayomie, O.S.; Kandeel, H.; Shoeib, T.; Yang, H.; Youssef, N.; El-Sayed, M.M.H. Novel approach for effective removal of methylene blue dye from water using fava bean peel waste. Scientific Reports 2020, 10, 7824, https://doi.org/10.1038/s41598-020-64727-5.

50. Mavioglu Ayan, E.; Secim, P.; Karakaya, S.; Yanik, J. Oreganum stalks as a new biosorbent to remove textile dyes from aqueous solutions. CLEAN - Soil, Air, Water 2012, 40, 856-863, https://doi.org/10.1002/clen.201100153.

51. Ausavasukhi, A.; Kampoosaen, C.; Kengnok, O. Adsorption characteristics of Congo red on carbonized leonardite. Journal of Cleaner Production 2016, 134, 506-514, https://doi.org/10.1016/j.jclepro.2015.10.034.

52. Ferrarini, F.; Bonetto, L.R.; Crespo, J.S.; Giovanela, M. Removal of congo red dye from aqueous solutions using a halloysite-magnetite-based composite. Water Science and Technology 2016, 73, 2132-2142, https://doi.org/10.2166/wst.2016.060.

53. Liu, L.; Fan, S.; Li, Y. Removal behavior of methylene blue from aqueous solution by tea waste: kinetics, isotherms and mechanism. International Journal of Environmental Research and Public Health 2018, 15, 1321, https://doi.org/10.3390/ijerph15071321. 